\title{
Silver nanoparticles for the enhancement of accumulation of capsaicin in suspension culture of Capsicum sp.
}

\author{
Pooja Bhat ${ }^{1 *}$, Akash Bhat ${ }^{2}$ \\ 'Department of Botany, Ramnarain Ruia College of Arts and Science, University of Mumbai, Mumbai, Maharashtra, India, \\ ${ }^{2}$ Department of Chemical Engineering, Thadomal Shahani Engineering College, University of Mumbai, Mumbai, Maharashtra, India
}

Received: 04.03.2016

Revised: 14.03.2016

Accepted: 15.03 .2016

Published: 26.03 .2016

\section{*Address for} correspondence: Pooja Bhat, Indira Smruti, Bungalow No. 13, Mhada, Mulund East, Mumbai 400081, Maharashtra, India. Phone: +91-9892460575.

E-mail: poojapundalikbhat@ gmail.com

\begin{abstract}
Secondary metabolites can be very important chemicals for the development of plants. The secondary metabolite in this study is obtained from Capsicum. Capsaicin is industrially very important due to its wide use range. The study involved is the use of silver nanoparticles for elicitation of levels of capsaicin. Mediums with different hormonal combinations were prepared and growth was studied using qualitative analysis using iodine fumes, Gibbs Reagent and quantitative analysis using phosphomolybdic acid method and Folin-Ciocalteu method. This brings down a conclusion that the nanoparticles acted as an elicitor and brought about capsaicin increase effectively. Extraction of the metabolite from these natural sources also proves easier and the product can be obtained in a much purified form.
\end{abstract}

KEY WORDS: Capsicum, capsaisin, elicitor, secondary metabolite, silver nanoparticles

\section{INTRODUCTION}

Secondary metabolites act as an important chemical product for the development of plants (Croteau et al., 2000; Balandrin et al., 1985). One such important plant secondary metabolite is obtained from the genus Capsicum. Capsicum is known to encompass a wide variety of secondary metabolites namely ascorbic acid (vitamin C), carotenoids (provitamin A, tocopherols (vitamin E), flavonoids, and capsaicinoids (Heike and Knorr, 1995; Rao and Ravishankar, 2002; Bouvier et al., 2003). The capsaicinoids include capsaicin, dihydrocapsaicin, nordihydrocapsaicin, homodihydrocapsaicin, homocapsaicin, and non-ivamide. Capsaicin and dihydrocapsaicin account for approximately $90 \%$ of capsaicinoids in chili pepper fruit, are the two most potent capsaicinoids and their molecules differ only in the saturation of the acyl group (Reyes-Escogido Mde et al., 2011). Capsaicin can be commercially important.

The burning sensation caused by capsaicin on coming in contact with the mucous membranes has caused it to become a popular additive in food products requiring a heat or a spicy taste (Duarte et al., 2000). Although capsaicinoids have long been associated to the food industry, recent applications have been extended to other fields. Due to a decrease of sensitivity of skin or mucous membranes after repeated contact with capsaicinoids, they are now used for the treatment of rheumatic and some other pain-causing affections (Govindarajan and Sathyanarayana, 1991; Markovits and Gilhar, 1997). Application of capsaicin cream can be in chronic distal painful polyneuropathy (Low et al., 1995). There is a wide range of capsaicin application in clinical and medical industry (Epstein and Marcoe, 1994; Petsche et al., 1983; Bernstein et al., 1987). Hence, this topic is very important for studies.

Plant tissue culture techniques have been used to bring about the production of a number of metabolites of medicinal importance. The callus and cell cultures suspended in a liquid media are treated to desired environmental conditions aseptically to bring about the production of the desired metabolite sometimes, elicitors are used. An "elicitor" may be defined as a substance which when introduced in small concentrations to a living cell system, initiates or improves the biosynthesis of specific compounds. Elicitation is the induced or enhanced biosynthesis of metabolites due to the addition of trace 
amounts of elicitors (Namdeo, 2007; Balandrin et al., 1985).

In this current project, the production of capsaicin was done by growing callus cultures from chili explants on a suitable Murashige and Skoog (MS) defined medium. Once of considerable size, they calli were then transferred to the same MS (Murashige and Skoog, 1962) defined liquid medium to be kept on a shaker for a designated number of days. Each flask suspended with the callus was treated to a 50 ppm solution of silver nanoparticles that was used as an elicitor to bring about elicitation in the levels of capsaicin.

\section{MATERIALS AND METHODS}

\section{Media for Callus Culture}

The explant taken was from Capsicum frutescens. The growth medium taken into consideration was MS basal medium (defined). Four types of media were used with different plant growth hormones to test the best suited medium for the growth of the explant into a callus. Appropriate amounts of the stock solutions are added to distilled water in a separate flask to make the volume to $1 \mathrm{~L}$. Each stock solution is made up of varying concentrations of salts and nutrients. These varying concentrations bring about the growth of the callus. A detailed account of the nutrients is enlisted below.

Macronutrients $(\times 20)$ consisted of ammonium nitrate - $1650 \mathrm{mg} / \mathrm{L}$; calcium chloride - $440 \mathrm{mg} / \mathrm{L}$; manganese sulfate - $370 \mathrm{mg} / \mathrm{L}$; potassium nitrate - $1900 \mathrm{mg} / \mathrm{L}$; potassium phosphate - $170 \mathrm{mg} / \mathrm{L}$. Micronutrients $(\times 100)$ as boric acid - $6.2 \mathrm{mg} / \mathrm{L}$; cobalt chloride - $0.03 \mathrm{mg} / \mathrm{L}$; cupric sulfate - $0.03 \mathrm{mg} / \mathrm{L}$; manganese sulfate - $22.3 \mathrm{mg} / \mathrm{L}$; potassium iodide - $0.83 \mathrm{mg} / \mathrm{L}$; sodium molybdate - $0.25 \mathrm{mg} / \mathrm{L}$; zinc sulfate - $8.6 \mathrm{mg} / \mathrm{L}$. Vitamins $(\times 100)$ glycine - $2 \mathrm{mg} / \mathrm{L}$; inositol - $100 \mathrm{mg} / \mathrm{L}$; nicotinic acid/niacin - $0.5 \mathrm{mg} / \mathrm{L}$; pyridoxine $\mathrm{HCl}-0.5 \mathrm{mg} / \mathrm{L}$; thiamine $\mathrm{HCl}-0.1 \mathrm{mg} / \mathrm{L}$. Iron source $\times 200$ as ferrous sulfate $-27.8 \mathrm{mg} / \mathrm{L} ; \mathrm{Na}_{2}$ ethylenediaminetetraacetic acid, $37.2 \mathrm{mg} / \mathrm{L}$. The $\mathrm{pH}$ of the medium is set in between pH 5.6 and 5.8. Solidifying the medium for slant preparation is done by adding $1 \%$ agar and is added only after the $\mathrm{pH}$ is set. For defined media, plant growth hormones are added in fixed concentrations taking into consideration the explant and also the callus growth requirement, i.e., rooting or shooting. In the current experiment, four sets of defined media were prepared. The hormones are added using the above formula, from a stock having concentration of $1 \mathrm{mg} / 10 \mathrm{ml}$. The hormones are added post adjustment of $\mathrm{pH}$ and before the addition of agar.
Medium with Different Hormonal Combinations and Concentrations

1. MS (basal) $+5 \mathrm{mg} / \mathrm{L}$ 6-benzylaminopurine $(\mathrm{BA})+$ $0.1 \mathrm{mg} / \mathrm{L} \alpha$-naphthaleneacetic acid (NAA)

2. MS (basal) $+5 \mathrm{mg} / \mathrm{L}$ adenine sulfate $+0.1 \mathrm{mg} / \mathrm{LNAA}$

3. $\mathrm{MS}$ (basal) $+5 \mathrm{mg} / \mathrm{L} \mathrm{BA}+3 \mathrm{mg} / \mathrm{L} \mathrm{AgNO}_{3}$ (nanoparticles)

4. MS (basal) $+2 \mathrm{mg} / \mathrm{L} 2,4$-dichlorophenoxyacetic acid $(2,4-\mathrm{D})+1 \mathrm{mg} / \mathrm{L}$ kinetin.

About $60 \mathrm{ml}$ (4 tubes) of the above defined media was prepared and was used as a slant for the inoculation of the explant. The leaf, shoot, node/internode of the explant was placed aseptically in 3 of the tubes. In the last tube, the placenta along with one-two seeds from the bell pepper fruit was inoculated.

\section{Growth Studies for the Callus}

All the inoculated tubes were checked on a daily bases for the contamination and for callusing. Once the callus had grown to a desire size, 0.3-0.5 g of the callus was weighed and suspended in $40 \mathrm{ml}$ of the liquid media in 3 flasks each. The flasks were kept for 3 days, 6 days, and 9 days on a shaker. To each flask, $5 \mathrm{ml}$ of silver nanoparticle solution was added, i.e. to give a $50 \mathrm{ppm}$ concentration of nanoparticles, before placing on the shaker. A control flask was kept with only callus suspended in liquid medium without nanoparticles. The experiment was carried out in duplicates. The callus was then used to conduct tests as per the quantitative and qualitative estimations for capsaicin content.

\section{Silver Nanoparticles Solution Preparation}

About $5 \mathrm{~g}$ of plant extract was cut into small pieces and boiled with $50 \mathrm{ml}$ of deionized water for $10 \mathrm{~min}$. The solution was filtered through muslin cloth and centrifuged. The filtrate was used as the reducing agent for the preparation of silver nanoparticles. About $1 \mathrm{~g}$ of plant extract was added to $9 \mathrm{ml}$ of $1 \mathrm{mM}$ silver nitrate solution and kept at room temperature. The color change from yellow to brown indicates the reduction of pure $\mathrm{Ag}^{+}$ ions to silver metal nanoparticles.

\section{Methods}

\section{Qualitative estimation of capsaicin}

Qualitative estimation of capsaicin was conducted using liquid thin layer chromatography (TLC). The chromatography was conducted on both silica gel coated over aluminum and also silica gel coated over a glass slide. Reagents used were methanol, chloroform, acetic acid, Gibb's reagent (2,6-dichloroquinone-4chloroimide), 
iodine fumes, ammonia fumes, chloroform:acetic acid:methanol as $9.5 \mathrm{ml}: 0.5 \mathrm{ml}: 0.1 \mathrm{ml}$ (volume basis).

\section{Extract Preparation}

The samples used were fresh Capsicum fruit, Capsicum annum, C. frutescens, callus from the liquid medium for day 6 and day 9 . About $1 \mathrm{~g}$ each of the three samples is taken and crushed in $5 \mathrm{ml}$ of methanol. The C. annum and $C$. frutescans being dry samples are initially allowed to soak in methanol till the methanol starts acquiring some color. The extract is then refluxed for $10 \mathrm{~min}$. The refluxed sample is then collected and allowed to cool and reconstituted in $5 \mathrm{ml}$ methanol. About $1 \mathrm{ml}$ out of the extract is taken in a petri plate and allowed to evaporate till it gets concentrated. The above sample further was subjected to TLC. TLC chamber was spree saturated with the mobile phase and the plates once loaded are then placed in the chamber and allowed to run till about $3 / 4^{\text {th }}$ the length of the plate.

Before the drying begins, the solvent front is marked lightly at one side of the plate.

Once the solvent has run the plates are removed and air dried till the solvent traces have been lost completely. Two methods were further used and $R_{f}$ is the retention factor.

\section{Using iodine fumes}

As the solvent system is running, in another chamber, some iodine crystals were taken and the chamber was covered with a Petri plate and allowed to saturate. After the chromatogram on the aluminum plate was dried, it was immediately placed in the iodine fumes saturated chamber to bring about the development of the capsaicin spot that appeared brown in color. The plate was then taken and used for calculating the retention factor of $R_{f}$ value.

\section{Using Gibb's reagent}

Another solvent system that was used is the Gibb's reagent, also known as 2,6-dichloroquinone-4chloroimide. It was prepared by dissolving $0.5 \mathrm{~g}$ of the reagent in $100 \mathrm{ml}$ of methanol. The plate once it run was dipped in the Gibb's reagent and then let to dry. As the reagent was drying, another chamber was simultaneously set up containing ammonia fumes. Once the reagent had dried, the plate was then exposed to the ammonia fumes to bring about the development of the spot.

\section{Quantitative estimation of capsaicin}

Phosphomolybdic acid, 20.4\% $\mathrm{NaOH}$, methanol were used.
Phosphomolybdic acid method (Singleton and Rossi, 1965)

About $1 \mathrm{~g}$ of material was taken and extracted in $5 \mathrm{ml}$ of methanol. In case of dry material like chili, the material was first allowed to soak till the methanol acquired color. The material was then refluxed for $10 \mathrm{~min}$. After cooling, the sample was reconstituted in $5 \mathrm{ml}$ of methanol. The sample was then centrifuged and the supernatant was used for the following test. Bismuth nitrate was prepared in the concentrations of $0.2,0.4,0.6,0.8$, and 1 and the volume made up to $1 \mathrm{ml}$ using $\mathrm{D} / \mathrm{W}$. The tubes were treated to the following chemicals and optical density (OD) taken at $650 \mathrm{~nm}$ to provide a standard graph for quantitative estimation of capsaicin. About $1 \mathrm{ml}$ of the sample extract of the supernatant is allowed to evaporate. To the evaporated sample, $2 \mathrm{ml}$ of $0.4 \% \mathrm{NaOH}$ is added and mixed thoroughly. About $6 \mathrm{ml}$ of phosphomolybdic acid is added to the above sample and is mixed and kept aside for $1 \mathrm{~h}$. The OD is then read at $650 \mathrm{~nm}$. In case if the solution is dark in color, it is diluted before taking the reading.

\section{Quantitative estimation of the total phenolic content}

Reagents used were methanol, Folin's-Ciocaltu reagent (dilute the Folin's reagent by taking $0.5 \mathrm{ml}$ of the original solution and diluting it to $5 \mathrm{ml}$ with distilled water), $7.5 \%$ $\mathrm{Na}_{2} \mathrm{CO}_{3}, 0.01 \mathrm{~g}$ of gallic acid dissolved in $10 \mathrm{ml}$ of $\mathrm{D} / \mathrm{W}$.

Folin's-Ciocalteu method

About $1 \mathrm{~g}$ of material was taken and extracted in $5 \mathrm{ml}$ of methanol. In case of dry material like chili, the material was first allowed to soak till the methanol acquired color. The material was then refluxed for $10 \mathrm{~min}$. After cooling, the sample was reconstituted in $5 \mathrm{ml}$ of methanol. The sample was then centrifuged and the supernatant was used for the following test. To $1 \mathrm{ml}$ of the diluted Folin's reagent, add $2 \mathrm{ml}$ of $7.5 \% \mathrm{Na}_{2} \mathrm{CO}_{3}$. To the above mixture, add $1 \mathrm{ml}$ of the plant extract prepared. Various concentrations of Gallic acid was prepared i.e. 0.2, 0.4, 0.6, 0.8, and 1. The volume was made up to $1 \mathrm{ml}$ using $\mathrm{D} / \mathrm{W}$. This was used as the standard for the quantitative estimation of phenols. About $1 \mathrm{ml}$ of diluted Folin's reagent was added to each tube, to which $2 \mathrm{ml}$ of $7.5 \% \mathrm{Na}_{2} \mathrm{CO}_{3}$ was added. All the tubes were vortexed for about $10 \mathrm{~s}$. They were then kept in a warm water bath for $15 \mathrm{~min}$. The OD was taken at $765 \mathrm{~nm}$.

\section{RESULTS}

Callus extract control is used for comparison between use of silver nanoparticles and control culture. Control culture is without the use of nanoparticles. 


\section{Growth Results Interpretation for Callus}

Among the four media, MS media with different hormonal combinations and concentration used for the growth of the callus, the media MS (basal) $+2 \mathrm{mg} / \mathrm{L} 2,4-\mathrm{D}+1 \mathrm{mg} / \mathrm{L}$ kinetin, it was proved to give the best for the formation of a callus within a short period of time (2 weeks). All the explants showed immediate callusing; however, the

Table 1: Results for MS (basal) $+5 \mathrm{mg} / \mathrm{L} \mathrm{BA}+0.1 \mathrm{mg} / \mathrm{L} \mathrm{NAA}$

\begin{tabular}{|c|c|c|c|}
\hline $\begin{array}{l}\text { Study } \\
\text { parameter }\end{array}$ & Day 1 & Day 7 & Day 14 \\
\hline Shoot & - & - & - \\
\hline Internode & $\begin{array}{l}\text { Swelling } \\
\text { (no contamination) }\end{array}$ & $\begin{array}{l}\text { Swelling persists } \\
\text { (no contamination) }\end{array}$ & - \\
\hline Leaf & $\begin{array}{l}\text { Swelling } \\
\text { (no contamination) }\end{array}$ & $\begin{array}{l}\text { Swelling persists } \\
\text { (no contamination) }\end{array}$ & - \\
\hline Placenta & $\begin{array}{l}\text { Very slight swelling } \\
\text { (no contamination) }\end{array}$ & $\begin{array}{l}\text { No change } \\
\text { (no contamination) }\end{array}$ & $\begin{array}{l}\text { No change observed } \\
\text { (No contamination) }\end{array}$ \\
\hline
\end{tabular}

MS: Murashige and Skoog, BA: 6-benzylaminopurine,

NAA: $\alpha$-naphthaleneacetic acid

Table 2: MS (basal) $+5 \mathrm{mg} / \mathrm{L}$ Ads $+0.1 \mathrm{mg} / \mathrm{L}$ NAA

\begin{tabular}{llll}
\hline $\begin{array}{l}\text { Study } \\
\text { parameter }\end{array}$ & Day 1 & Day 7 & Day 14 \\
\hline $\begin{array}{l}\text { Shoot } \\
\text { Internode }\end{array}$ & $\begin{array}{l}\text { Swelling } \\
\text { (no contamination) }\end{array}$ & $\begin{array}{l}\text { Swelling persists } \\
\text { (no contamination) }\end{array}$ & - \\
Leaf & $\begin{array}{l}\text { Swelling } \\
\text { (no contamination) }\end{array}$ & $\begin{array}{l}\text { Swelling persists } \\
\text { (no contamination) }\end{array}$ & $\begin{array}{l}\text { Tube showed } \\
\text { contamination } \\
\text { Placenta }\end{array}$ \\
& $\begin{array}{l}\text { Very slight swelling } \\
\text { (no contamination) }\end{array}$ & No change contamination) & $\begin{array}{l}\text { No change observed } \\
\text { (no contamination) }\end{array}$ \\
\hline
\end{tabular}

MS: Murashige and Skoog, NAA: $\alpha$-naphthaleneacetic acid,

Ads: Adenine sulfate

Table 3: MS (basal) $+5 \mathrm{mg} / \mathrm{L} \mathrm{BA}+3 \mathrm{mg} / \mathrm{L} \mathrm{AgNO}_{3}$ (nanoparticles)

\begin{tabular}{llll}
\hline $\begin{array}{l}\text { Study } \\
\text { parameter }\end{array}$ & Day 1 & Day 7 & Day 14 \\
\hline $\begin{array}{l}\text { Shoot } \\
\text { Internode }\end{array}$ & $\begin{array}{l}\text { Slight swelling } \\
\text { (no contamination) }\end{array}$ & $\begin{array}{l}\text { No visible change } \\
\text { (no contamination) }\end{array}$ & $\begin{array}{l}\text { Tube showed } \\
\text { contamination }\end{array}$ \\
Leaf & $\begin{array}{l}\text { Slight swelling } \\
\text { (no contamination) }\end{array}$ & $\begin{array}{l}\text { No visible change } \\
\text { (no contamination) }\end{array}$ & $\begin{array}{l}\text { Tube showed } \\
\text { contamin }\end{array}$ \\
Placenta & $\begin{array}{l}\text { No swelling } \\
\text { (no contamination) }\end{array}$ & $\begin{array}{l}\text { No swelling } \\
\text { (no contamination) }\end{array}$ & $\begin{array}{l}\text { No change observed } \\
\text { (no contamination) }\end{array}$ \\
\hline
\end{tabular}

MS: Murashige and Skoog, NAA: $\alpha$-naphthaleneacetic acid,

BA: 6-benzylaminopurine placenta and seed inoculation in all of the four media did not show any kind of swelling or initiation of callusing. All the results are shown in Tables 1-4.

\section{Results of Quantitative and Qualitative Estimation}

\section{Qualitative estimation result}

TLC analysis using iodine fumes

The retention factor $R_{f}$ values are listed in Table 5 .

TLC analysis using Gibb's reagent

The plate however did not show the presence of any spots, and hence it did not prove as a useful method for the qualitative estimation of capsaicin.

TLC analysis for the callus extract

The callus extract was used as a sample and spotted onTLC plates. The callus extracts of control, on day 6 and day 9 , were run for TLC analysis as shown in Table 6.

\section{Quantitative Estimation}

\section{Results for capsaicin estimation by phosphomolybdic acid test}

The equation $y=0.54 x+0.038$ is used for further estimation of the sample concentration. The results are shown in Table 7.

The capsaicin estimation by phosphomolybdic acid test showed highest capsaicin content in callus extract after day $6(29.829,31.95)$ followed by day $9(32.695,30.523)$, day $3(16.043,14.844)$, C. frutescens $(6.148,5.7770$, C. annum (5.962, 5.407), Capsicum (5.592, 5.222), and control $(0.787,1.443)$.

\section{Results for total phenolic estimation by Folin's-Ciocalteu method}

The equation $y=0.6029 x+0.0119$ is used for further estimation of the sample concentration. The results are shown in Table 8.

The total phenolic estimation carried out by the Folin'sCiocalteu method showed highest amount of phenols in callus extract after day $6(11.098,10.928)$ followed by day

Table 4: MS (basal) $+2 \mathrm{mg} / \mathrm{L} \mathrm{2,4-D+1} \mathrm{mg/L} \mathrm{kinetin}$

\begin{tabular}{|c|c|c|c|c|}
\hline $\begin{array}{l}\text { Study } \\
\text { parameter }\end{array}$ & Day 1 & Day 7 & Day 14 & Day 24 \\
\hline Shoot & Slight swelling & Increase in swelling & Prominent initiation of callusing & Steady callusing, used for further tests \\
\hline Node & Swelling & Slight initiation of callusing & Good callusing observed & Steady callusing, used for further tests \\
\hline Internode & Swelling & Further swelling & Moderate callusing observed & Steady callusing used for further tests \\
\hline & Prominent swelling & Initiation of callusing & Good callusing observed & Steady callusing, used for further tests \\
\hline Flower & Very slight swelling & Increase in swelling in shoot region & Good callusing observed in the shoot area & Shoot region used for further tests \\
\hline Placenta & No change & No change & No change & Tube discarded \\
\hline
\end{tabular}

MS: Murashige and Skoog, 2,4-D: 2,4-dichlorophenoxyacetic acid 
Table 5: Results for TLC analysis - Iodine fumes

\begin{tabular}{lc}
\hline Plant material (fresh) & \multicolumn{1}{c}{$R_{f}$ value } \\
\hline Capsicum & Spot $1=0.185$ \\
& Spot $2=0.642$ \\
C. frutescens & Spot $1=0.785$ \\
C. annum & Spot $1=0.385$ \\
& Spot $2=0.685$ \\
& Spot $3=0.771$ \\
\hline
\end{tabular}

C. frutescens: Capsicum frutescens, C. annum: Capsicum annum,

TLC: Thin layer chromatography

Table 6: TLC analysis of callus extract

\begin{tabular}{lc}
\hline Callus extract & $R_{f}$ value \\
\hline Control & Spot $1=0.692$ \\
& Spot $2=0.75$ \\
Callus (day 6) & Spot $1=0.714$ \\
Callus (day 9) & Spot $1=0.746$ \\
\hline
\end{tabular}

TLC: Thin layer chromatography

Table 7: Results for phosphomolybdic acid test

\begin{tabular}{|c|c|c|c|c|}
\hline $\begin{array}{l}\text { Study } \\
\text { parameter }\end{array}$ & $\begin{array}{l}\text { OD }(660 \mathrm{~nm}) \\
\text { Set } 1\end{array}$ & $\begin{array}{c}\text { Concentration } \\
\mathrm{mg} / \mathrm{g}\end{array}$ & $\begin{array}{l}\text { OD (660 nm) } \\
\text { Set } 2\end{array}$ & $\begin{array}{c}\text { Concentration } \\
\mathrm{mg} / \mathrm{g}\end{array}$ \\
\hline Capsicum & 0.34 & 5.592 & 0.32 & 5.222 \\
\hline C. frutescens & 0.37 & 6.148 & 0.35 & 5.777 \\
\hline C. annum & 0.36 & 5.962 & 0.33 & 5.407 \\
\hline $\begin{array}{l}\text { Callus extract } \\
\text { (control) }\end{array}$ & 0.05 & 0.787 & 0.04 & 1.443 \\
\hline $\begin{array}{l}\text { Callus extract } \\
\text { (day } 3 \text { ) }\end{array}$ & 0.44 & 16.043 & 0.41 & 14.844 \\
\hline $\begin{array}{l}\text { Callus extract } \\
\text { (day 6) }\end{array}$ & 0.51 & 29.829 & 0.53 & 31.095 \\
\hline $\begin{array}{l}\text { Callus extract } \\
\text { (day 9) }\end{array}$ & 0.49 & 32.695 & 0.46 & 30.523 \\
\hline
\end{tabular}

C. frutescens: Capsicum frutescens, C. annum: Capsicum annum, OD: Optical density

Table 8: Results for OD reading for Folin's-Ciocalteu test

\begin{tabular}{lcccc}
\hline $\begin{array}{l}\text { Study } \\
\text { parameter }\end{array}$ & $\begin{array}{c}\text { OD }(700 \mathrm{~nm}) \\
\text { Set } 1\end{array}$ & $\begin{array}{c}\text { Concentration } \\
\mathrm{mg} / \mathrm{g}\end{array}$ & $\begin{array}{c}\text { OD }(700 \mathrm{~nm}) \\
\text { Set } 2\end{array}$ & $\begin{array}{c}\text { Concentration } \\
\mathrm{mg} / \mathrm{g}\end{array}$ \\
\hline Capsicum & 0.19 & 2.954 & 0.21 & 3.285 \\
C. frutescens & 0.16 & 2.456 & 0.18 & 2.788 \\
C. annum & 0.12 & 1.793 & 0.11 & 1.627 \\
$\begin{array}{l}\text { Callus extract } \\
\text { (control) }\end{array}$ & 0.02 & 0.475 & 0.03 & 1.063 \\
$\begin{array}{l}\text { Callus extract } \\
\text { (day 3) }\end{array}$ & 0.09 & 2.790 & 0.11 & 2.506 \\
$\begin{array}{l}\text { Callus extract } \\
\text { (day 6) }\end{array}$ & 0.208 & 11.098 & 0.205 & 10.928 \\
$\begin{array}{l}\text { Callus extract } \\
\text { (day 9) }\end{array}$ & 0.125 & 7.324 & 0.127 & 7.457 \\
\hline
\end{tabular}

C. frutescens: Capsicum frutescens, C. annum: Capsicum annum, OD: Optical density

9 (7.342, 7.457), Capsicum (2.954, 3.285), day 3 (2.790, 2.506), C. frutescens $(2.456,2.788)$, C. annum (1.792, $1.627)$, and control $(0.475,1.063)$.

\section{CONCLUSION}

Capsaicin has gained commercial importance due to its use in the medical, food, defense, pest, and sports industries.
Due to its increased demand, the production on a large scale has to be facilitated. The only challenge being faced for the production of any secondary metabolite is the lack of knowledge about the biosynthetic pathway that exists in the plants which brings about the production of the metabolite. The same case being with capsaicin, its synthetic production does not match up to the demand levels.

The use of in vitro techniques for the production of secondary metabolites with the direct use of the callus is rare as compare to the use of immobilized cells. Cell cultures of Capsicum annuum L. were obtained from seedlings on MS medium supplemented with 2,4-D and kinetin. In vitro-grown cells and placental tissues from fruits were immobilized in calcium alginate. Ferulic acid fed to immobilized placenta at $2.5 \mathrm{mM}$ level increased capsaicin production by 2 -fold by the $5^{\text {th }}$ day of the culture period. Production reached a level of $1345 \mu \mathrm{g}$ capsaicin/g of immobilized placenta on the $14^{\text {th }}$ day of culture. Production of capsaicin, on replenished nutrient medium in immobilized placenta was $2400 \mu \mathrm{g}$ on the $30^{\text {th }}$ day.

In the current project, the callus cultures of C. frutescens were grown and suspended in a liquid medium containing 2,4-D an kinetin in the presence of silver nanoparticles as an elicitor. The cells were not immobilized. The quantitative and statistical analysis shows significant increase in the amount of capsaicin as compared to the Capsicum fruit, even without immobilization. The highest amount of capsaicin content was found on the $6^{\text {th }}$ day. The increase was approximately 2 -fold in between the $3^{\text {rd }}$ and the $6^{\text {th }}$ day. This however brings down a conclusion that the nanoparticles acted as an elicitor and brought about capsaicin increase effectively.

In vitro methods for the production of secondary metabolites are being exploited to a wide range. There are significant challenges that are being faced for the synthetic production of the metabolites due to difficulty in decoding the biosynthetic pathway of the secondary metabolites. Hence, in vitro methods such as plant tissue culture and free cell suspensions in bioreactors prove as promising methods to obtain the product in its natural form. Extraction of the metabolite from these natural sources also proves easier and the product can be obtained in a much purified form.

\section{ACKNOWLEDGMENTS}

We would like to thank the Professors of Ruia college for guiding a Similar project for Masters Thesis. Thank you to Labs from Ruia College and Thadomal Shahani Engineering College for providing Resources. 


\section{REFERENCES}

Balandrin MF, Klocke JA, Wurtele ES, Bollinger WH. Natural plant chemicals: Sources of industrial and medicinal materials. Science 1985;228:1154-60.

Bernstein JE, Bickers DR, Dahl MV, Roshal JY. Treatment of chronic postherpetic neuralgia with topical capsaicin. A preliminary study. J Am Acad Dermatol 1987;17:93-6.

Bouvier F, Suire C, Mutterer J, Camara B. Oxidative remodeling of chromoplast carotenoids: Identification of the carotenoid dioxygenase CsCCD and CsZCD genes involved in Crocus secondary metabolite biogenesis. Plant Cell 2003;15:47-62.

Croteau R, Kutchan TM, Lewis NG. Natural products (secondary metabolites). Biochem Mol Biol Plants 2000;24:1250-319.

Heike D, Knorr D. Strategies for the improvement of secondary metabolite production in plant cell cultures. Enzyme Microb Technol 1995;17:674-84.

Duarte DR, Castillo E, Bárzana E, López-Munguía A. Capsaicin hydrolysis by Candida antarctica lipase. Biotechnol Lett 2000;22:1811-4.

Epstein JB, Marcoe JH. Topical application of capsaicin for treatment of oral neuropathic pain and trigeminal neuralgia. Oral Surg Oral Med Oral Pathol 1994;77:135-40.

Govindarajan VS, Sathyanarayana MN. Capsicum - Production, technology, chemistry, and quality. Part V. Impact on physiology, pharmacology, nutrition, and metabolism; structure, pungency, pain, and desensitization sequences. Crit Rev Food Sci Nutr 1991;29:435-74.

Low PA, Opfer-GehrkingTL, Dyck PJ, Litchy WJ, O’Brien PC. Double-blind, placebo-controlled study of the application of capsaicin cream in chronic distal painful polyneuropathy. Pain 1995;62:163-8.

Markovits E, Gilhar A. Capsaicin - An effective topical treatment in pain. Int J Dermatol 1997;36:401-4.

Murashige T, Skoog F. A revised medium for rapid growth and bio assays with tobacco tissue cultures. Physiol Plant 1962;15:473-97.

Namdeo AG. Plant cell elicitation for production of secondary metabolites: A review. Pharmacogn Rev 2007;1:69-79.

Petsche U, Fleischer E, Lembeck F, Handwerker HO. The effect of capsaicin application to a peripheral nerve on impulse conduction in functionally identified afferent nerve fibres. Brain Res 1983;265:233-40.

Rao SR, Ravishankar GA. Plant cell cultures: Chemical factories of secondary metabolites. Biotechnol Adv 2002;20:101-53.

Reyes-Escogido Mde L, Gonzalez-Mondragon EG, VazquezTzompantzi E. Chemical and pharmacological aspects of capsaicin. Molecules 2011;16:1253-70.

Singleton VL, Rossi JA. Colorimetry of total phenolics with phosphomolybdic-phosphotungstic acid reagents. Am J Enol Vitic 1965;16:144-58. 